\title{
$\nabla$
}

\section{Disseminated tungiasis}

\author{
Tungíase disseminada
}

Andrelou Fralete Ayres Vallarelli ${ }^{1}$

\author{
Elemir Macedo de Souza ${ }^{2}$
}

\begin{abstract}
Tungiasis is a zoophilic and anthropophilic infestation caused by Tunga penetrans. It is endemic in Latin America and in the Caribbean. It occurs mainly in impoverished communities that have no access to basic sanitation and in individuals that visit contaminated areas. The most common penetration site of this ectoparasite is the periungueal region of the feet. The authors present its disseminated form occurring in a patient inhabiting a rural area.

Keywords: Basic sanitation; Communicable diseases; Ectoparasitic infestations; Siphonaptera

Resumo: A tungíase é uma infestação zooantropofílica causada pela Tunga penetrans. É endêmica na América Latina e no Caribe. Ocorre, principalmente, em comunidades carentes e sem saneamento básico e em indivíduos que visitam áreas contaminadas. O local mais comum de penetração do ectoparasita é a região periungueal dos pés. Os autores mostram a ocorrência de uma forma disseminada num habitante da zona rural.

Palavras-chave: Doenças transmissíveis; Ectoparasitoses; Sifonápteros; Saneamento básico
\end{abstract}

Tungiasis is a zooanthropophylic infestation caused by infection by the gravid female of the Tunga penetrane flea, a hematophagous ectoparasite that inhabits dry, sandy soil and spreads principally during the dry season (Figure 1). 1-3 Maturation occurs between 8 and 12 days and the enlarged abdomen of the flea can contain as many as 200 eggs or more. It is endemic in Latin America, the Caribbean and sub-Saharan Africa. ${ }^{4}$ Trade and military routes spread the disease and cases exist in travelers to endemic areas $1 .^{5-6}$ The flea's burrowing ability favors penetration of the periungual region of the feet and occasionally the hands, elbows, thighs, face, buttocks and inguinal region (Figure 2). ${ }^{6-8}$ After penetration the site becomes inflamed and painful (Figures 3 and 4). Secondary infection may occur in the absence of treatment. Tetanus is a

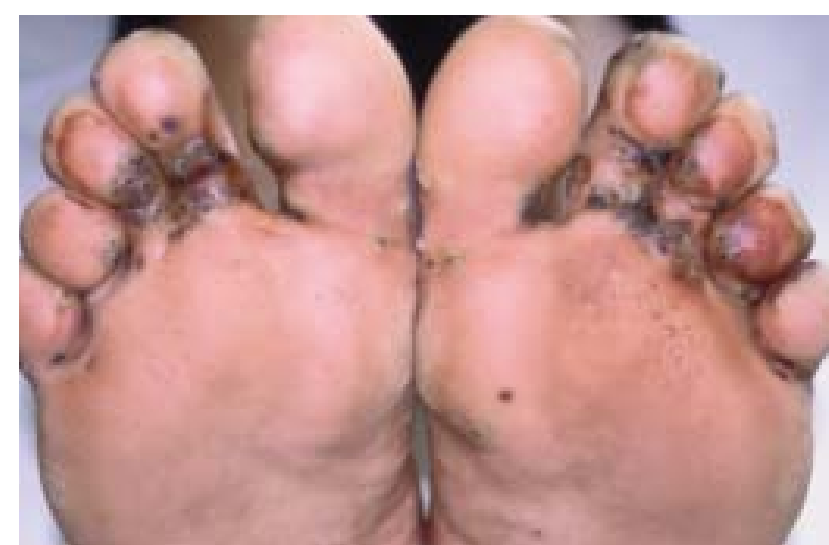

Figure 1: Male patient, 42 years-old, mulatto, from Hortlândia, São Paulo, with papular-nodular lesions showing black dots in the center, measuring between 5 and $8 \mathrm{~mm}$ in diameter, in the periungual, lateral and ventral sides of the toes and plantar areas of the feet. Enucleation was performed in some lesions with a sterile needle and a single dose of ivermectin $200 \mathrm{mcg} / \mathrm{kg}$ was prescribed

Received on 22.02.2010.

Approved by the Advisory Board and accepted for publication on 31.08.2010

* Study conducted in the Dermatology Teaching Division, Department of Clinical Medicine, Faculty of Medical Sciences, State University of Campinas (UNICAMP), São Paulo (SP), Brazil.

Conflict of interest: None / Conflito de interesse: Nenbum

Financial funding: None / Suporte financeiro: Nenbum

Ph.D, private clinic, São Paulo (SP), Brazil.

Assistant Professor and Associate Senior Lecturer, Dermatology Teaching Division, Department of Clinical Medicine, Faculty of Medical Sciences, State University of Campinas (UNICAMP), São Paulo (SP), Brazil

(C)2011 by Anais Brasileiros de Dermatologia 


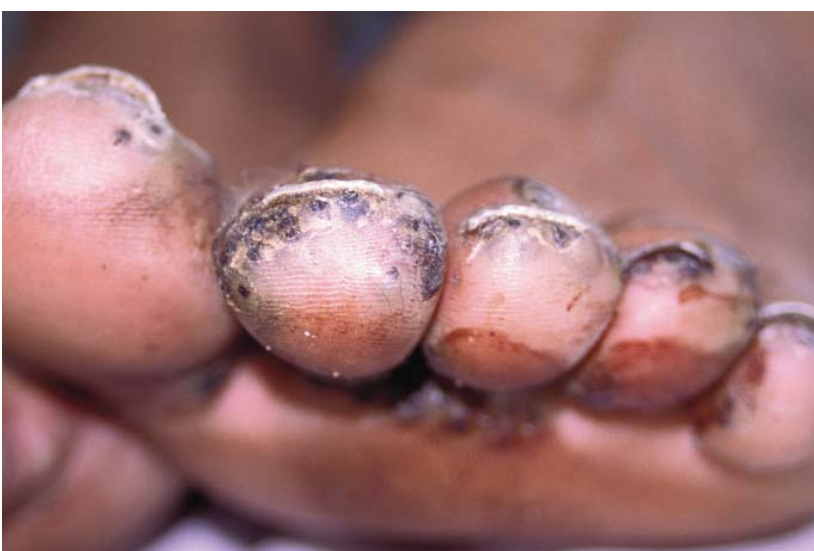

Figure 2: Periungual lesions on the left foot

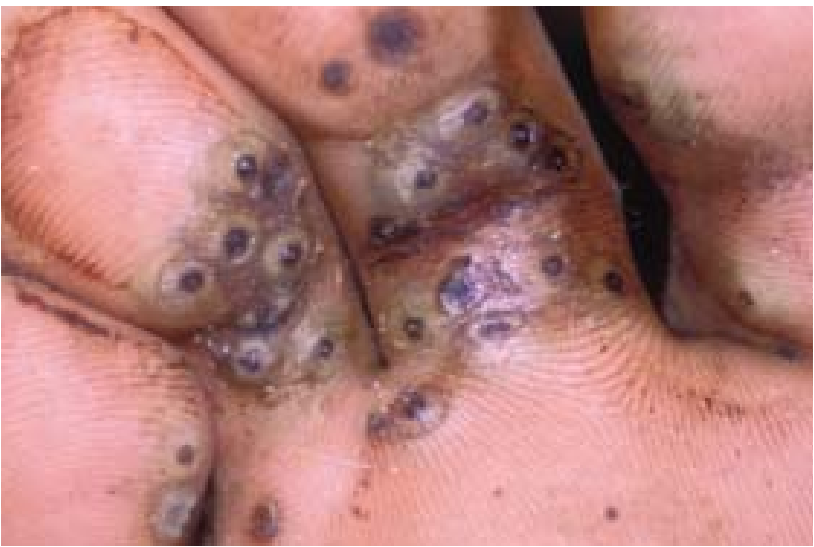

FigURE 3: Honeycombed appearance of the right plantar region

\section{REFERENCES}

1. Heukelbach J, de Oliveira FA, Hesse G, Feldmeier H. Tungiasis: a neglected health problem of poor communities. Trop Med Int Health. 2001;6:267-72.

2. Heukelbach J, Wilcke T, Harms G, Feldmeier H. Seasonal variation of tungiasis in an endemic community. Am J Trop Med Hyg. 2005:72:145-9.

3. Ugbomoiko US, Ariza L, Heukelbach J. Parasites of importance for human health in Nigerian dogs: high prevalence and limited knowledge of pet owners. BMC Vet Res. 2008;4:49.

4. Gatti FR, Oliveira CM, Gatti TRSR, Sanches APG. Tungíase disseminada tratada com ivermectina. An Bras Dermatol. 2008;83:339-42.

5. Hager J, Jacobs A, Orengo IF, Rosen T. Tungiasis in the United States: a travel souvenir. Dermatol Online J. 2008;14:3.

6. Ferreira LA, Piazza AA, Belda W Jr, de Souza EM, Ferreira Velho PE. Tunga penetrans as a traveler's disease. Travel Med Infect Dis. 2009;7:381-2.

7. Heukelbach J, Sahebali S, Van Marck E, Sabóia Moura RC, Feldmeier H. An unusual case of ectopic tungiasis with pseudoepitheliomatous hyperplasia. Braz $J$ Infect Dis. 2004;8:465-8.

8. Greco JB, Sacramento E, Tavares-Neto J. Chronic ulcers and myasis as ports of entry for Clostridium tetani. Braz J Infect Dis. 2001;5:319-23

9. Feldmeier H, Eisele M, Sabóia-Moura RC, Heukelbach J. Severe tungiasis in underprivileged communities: case series from Brazil. Emerg Infect Dis. 2003;9:949-55

10. Cardoso AEC. Tungíase. An Bras Dermatol. 1990;65(Supl 1):S29-33.

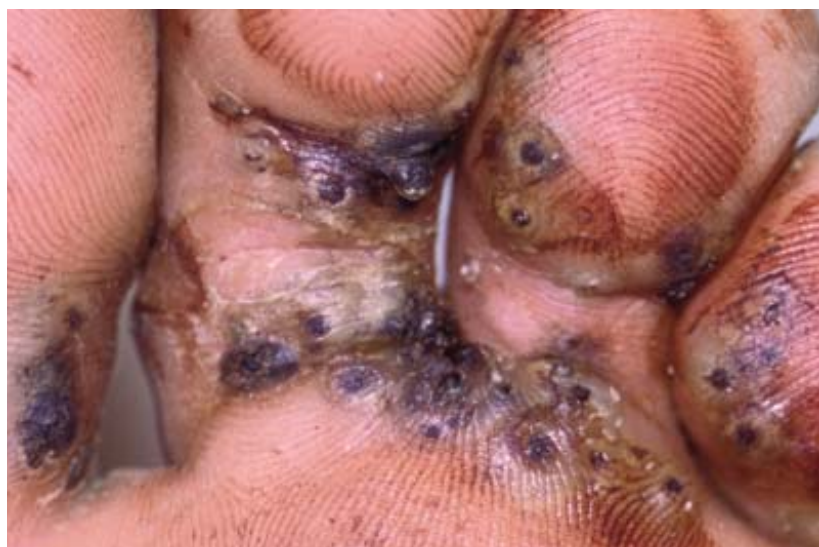

Figure 4: Detail of the lesions in the left plantar region

common complication. The disease is more prevalent in poor communities with no paved streets, where people walk barefoot. ${ }^{1.8-10}$ The diagnosis is clinical and treatment consists of removing the flea with a sterile needle.
MAILING ADDRESS / ENDEREÇO PARA CORRESPONDENNCIA: Andrelou Fralete Ayres Vallarelli Av. Barão de Itapura, 950 - Conjunto 44, Botafogo 13020-431 Campinas - SP, Brazil

Phone/fax: (19) 3234-2404/3201-6558 / 9790-8050

E-mail:andrelou@uol.com.br

How to cite this article/Como citar este artigo: Vallarelli AFA, Souza EM. Disseminated tungiasis. An Bras Dermatol. 2011;86(5):1027-8. 